\title{
Investigation of Antioxidant and In Vitro Wound Healing Activity of Fulvic Acid
}

\section{Özlem Sultan ASLANTÜRK ${ }^{1 *} \quad$ Tülay AŞKIN ÇELIKK ${ }^{1} \quad$ Yusuf Mert SÖNMEZ}

\begin{abstract}
This study aimed to investigate the antioxidant and in vitro wound healing activities of fulvic acid (FA) purified from Hüsamlar leonardite in Muğla/Turkey. Purified FA was analyzed with FT/IR spectrophotometer and flame photometer for determining functional groups and cation impurities, respectively. 1, 5, 10, 20, 30, 50, $100 \mu \mathrm{g} \mathrm{mL}^{-1}$ concentrations of FA were tested for antioxidant activity (by using DPPH radical scavenging and $\mathrm{H}_{2} \mathrm{O}_{2}$ scavenging assays). Also, effect of FA on BJ human foreskin fibroblast and $\mathrm{HaCaT}$ spontaneously immortalized non-tumorigenic human keratinocyte cells proliferation was tested by in vitro MTT and WST-8 assays and on cell migration by wound healing assay (scratch assay). The results of the study show that the FA has a low DPPH radical scavenging activity, but it exhibited high $\mathrm{H}_{2} \mathrm{O}_{2}$ scavenging activity at low concentrations. The effect of FA on the proliferation of $\mathrm{BJ}$ and $\mathrm{HaCaT}$ cells varied according to the cell type, FA concentration and treatment time. However, it accelerated wound healing by increasing cell migration, especially in HaCaT cells. 1 and $10 \mu \mathrm{g} \mathrm{mL}^{-1} \mathrm{FA}$ had a significant wound healing effect on BJ cells, and all concentrations of FA had a significant wound healing effect on HaCaT cells at the end of the $24 \mathrm{~h}$ treatments.
\end{abstract}

Keywords: Antioxidant activity, cell proliferation, fulvic acid, humic substance, wound healing

\footnotetext{
1' Özlem Sultan ASLANTÜRK (Orcid ID: 0000-0002-2503-0164), Tülay AŞKIN ÇELİK (Orcid ID: 0000-0001-68919089), Adnan Menderes University, Faculty of Art and Science, Department of Biology, Aydın, Turkey

${ }^{2}$ Yusuf Mert SÖNMEZ (Orcid ID: 0000-0001-8768-8749), ProSCon Mühendislik San. ve Tic. A.Ş., Ankara, Turkey *Corresponding author: Özlem Sultan ASLANTÜRK, e-mail: oaslanturk@adu.edu.tr
} 


\section{INTRODUCTION}

Skin is the largest organ in the body comprising approximately $15 \%$ of body weight and consists of epidermis and dermis. Furthermore, subcutaneous layer is present under the dermis. Epidermis is the outermost layer of the skin and it maintains a vital barrier against external trauma. The major cellular content of the epidermis is keratinocytes (approx. 95\% of the epidermis) and fibroblasts are major cellular component of the dermis (Zouboulis, 2000; Braun-Falco et al., 2000). When the outer covering of the skin, the epidermis, is injured a wound healing response is initiated. Wound healing is a complex process that occurs in different stages and involves many different cell types (Martin, 1997). Wound repair requires the proliferation and migration of fibroblasts and keratinocytes. These cells re-establish the normal cellular and extracellular matrix composition of skin, and the growth of vascular endothelial cells (VECs) to form new blood vessels that supply nutrients to the skin cells (Barrientos et al., 2008). The ability of these three cell types (fibroblasts, keratinocytes and VECs) to repair skin integrity and function is jeopardized in nonhealing wounds (Schafer and Warner, 2008).

Humic substances are formed from the decomposition of plants and occur naturally in water, peat, soil and brown coal. Humic substances have a complex structure and can be fractioned into humines, humic acids and fulvic acids (MacCarthy, 2001). Fulvic acid (FA), a class of compounds of humic substances, is a mixture of polyphenolic compounds formed through the degradation of organic substances such as plants, microbes and animals by chemical and biological processes (Motojima et al., 2011). FA has been reported recently to have nutraceutical properties and physiological action on the human body (Winkler and Ghosh, 2018). It is one of the naturally occurring phytochemicals with neuroprotective effect
(Cornejo et al., 2011; Guzmán-Martinez et al., 2013), antimicrobial and anti-inflammatory properties (Van Rensburg et al., 2001; Sherry et al., 2013).

Although with the presence of information about neuro-protective, antioxidant, antimicrobial and anti-inflammatory properties of various FA products and derivatives, no data have been reported previously on the in vitro wound healing activities of FA. Therefore, the aim of our study was to investigate the antioxidant and in vitro wound healing activities of FA purified from Hüsamlar leonardite in Muğla/Turkey on BJ human foreskin fibroblast cells and HaCaT spontaneously immortalized non-tumorigenic human keratinocyte cells.

\section{MATERIALS AND METHODS}

\section{Fulvic acid (FA) purification from Leonardite and FT/IR analysis}

In this research, a method of purification process of fulvic acid was aimed. Thus, two different processes yielding calcium fulvate and ethyl fulvic ester were developed. FA is purified by method of extraction, coagulation, vacuum distillation, esterification, solid-liquid seperation and ion exchange respectively (Smith and March, 2001). In experimental studies, produced amounts of calcium fulvate and ethyl fulvic ester from $100 \mathrm{~g}$ of Muğla Milas Hüsamlar leonardite were $832 \mathrm{mg}$ and $764 \mathrm{mg}$, respectively. After purification of these products, remaining amount of pure fulvic acid produced from ethyl fulvic ester and calcium fulvate were $800 \mathrm{mg}$ and 739 $\mathrm{mg}$, respectively. Thus, products were analyzed with FT/IR spectrophotometer in order to determine functional groups, and flame photometer was used for determining cation impurities (Fig. 1 and Fig. 2). After purification studies at laboratory scale, leonardite operating plants with a capacity of 1 tonne per hour were designed for each method. $14 \mathrm{~kg} /$ tonne raw material calcium fulvate was produced using 
Muğla Milas Hüsamlar leonardite (Sönmez 2011). Purified FA has carboxylic acid functional groups. Carboxyl acid groups are bonded with calcium and magnesium in coagulation phase of production process, and these ions are exchanged with sodium and hydrogen respectively. Carboxyl acid salts of calcium, magnesium, sodium and potassium are

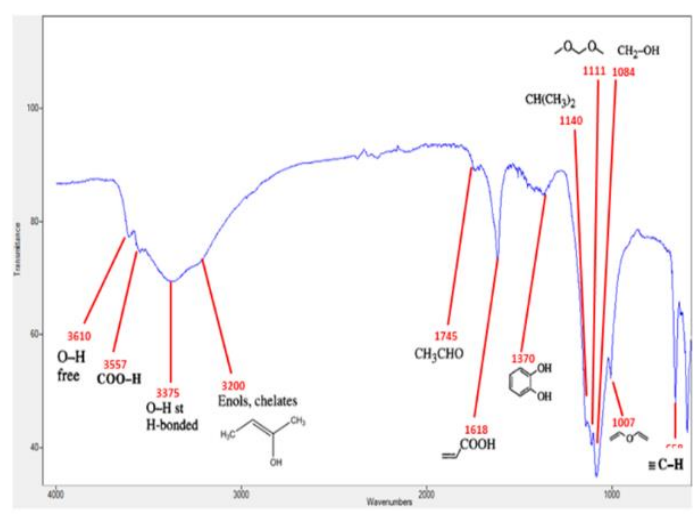

Fig.1.FT/IR analysis of ethyl fulvic ester

\section{Determination of antioxidant activity}

\section{DPPH (1,1-diphenyl-2-picrylhydrazyl) radical scavenging assay}

The free radical scavenging activity of FA was tested for its ability to bleach the stable 1,1diphenyl-2-picryl-hydrazyl radical (DPPH) (Brand-Williams et al.,1995). One milliliter of $0.1 \mathrm{mM}$ DPPH methanol solution was added to 3 $\mathrm{ml}$ of $1,5,10,20,30,50,100 \mu \mathrm{g} \mathrm{mL}$ concentrations of FA. The mixture was shaken vigorously and left at room temperature. After $30 \mathrm{~min}$, the absorbance of mixture was measured at $\lambda=517$. Tests were carried out in triplicate. Ascorbic acid $\left(10 \mu \mathrm{g} \mathrm{mL}^{-1}\right)$ and Rutin $(10 \mu \mathrm{g} \mathrm{mL}$ ${ }^{1}$ ), a citrus flavonoid glycoside, were used as standard.

\section{$\mathrm{H}_{2} \mathrm{O}_{2}$ scavenging assay}

Hydrogen peroxide scavenging activity of FA was determined by the method described by Ruch et al. (1989). A solution of $\mathrm{H}_{2} \mathrm{O}_{2}(40 \mathrm{mM})$ was prepared in phosphate buffer $(\mathrm{pH}$ 7.4). Reaction mixtures contained $40 \mathrm{mM}$ of $\mathrm{H}_{2} \mathrm{O}_{2}$ and changed to hydrogen with ion exchange stages of production. After these processes, the end product is two seperate FA components: Esterificiation product FA and Calcium salt precipitation product FA. Fulvic acid purchased from International Humic Substances Society (IHHS) was used as standard agent.

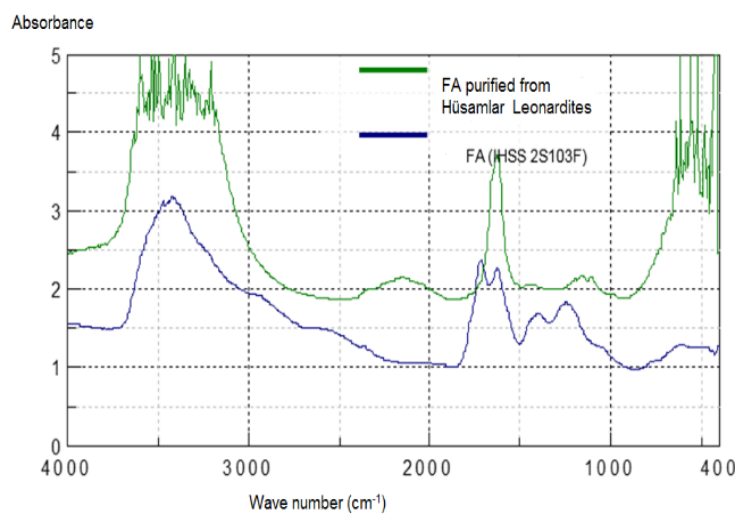

Fig. 2. FT/IR comparison of ethyl fulvic ester and pure fulvic acid

different FA concentrations (1, 5, 10, 20, 30, 50, $100 \mu \mathrm{g} \mathrm{mL} \mathrm{mL}^{-1)}$, and absorbance values were measured after 10 min using wavelength of 230 $\mathrm{nm}$. Ascorbic acid was used as the standard.

\section{Cell culture and proliferation assay (MTT and WST-8 assays)}

Human foreskin fibroblast cells (BJ) (ATCC CRL-2522) and a spontaneously immortalized nontumorigenic human keratinocyte cell line, HaCaT (CLS 300493 provided by Dr. Ersan KALAY, Karadeniz Techical University, Trabzon/TURKEY) were maintained in Eagle's minimal essential medium supplemented with $10 \%$ fetal bovine serum (FBS, Sigma-Aldrich, Germany), penicillin $\left(100 \mathrm{IUmL}^{-1}\right)$, and streptomycin $\left(100 \mu \mathrm{g} \mathrm{\textrm {mL } ^ { - 1 } )}\right.$ under humidified atmosphere of $5 \% \mathrm{CO}_{2}$ at $37^{\circ} \mathrm{C}$ until confluent. The cells were trypsinized and proliferation assays were carried out in 48 wellplates. BJ and HaCaT cells were seeded into 48well plates $\left(5 \times 10^{3}\right.$ cells per well) and incubated for $24 \mathrm{~h}$, during which a partial monolayer formed. After $24 \mathrm{~h}$ incubation, the cells were 
treated with $1,5,10$ and $20 \mu \mathrm{g} \mathrm{mL}^{-1} \mathrm{FA}$ for $24 \mathrm{~h}$ and $48 \mathrm{~h}$. Negative control cells received only culture medium. Crystalin (10\%) was used as standard wound healing agent for $\mathrm{BJ}$ and $\mathrm{HaCaT}$

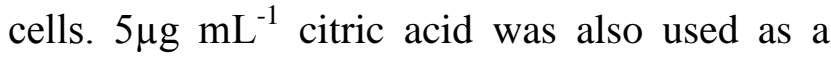
solvent control (solvent of FA). At the end of the treatment times, cellular viabilities were determined by MTT assay (Mossman 1983) and WST-8 assay (Tominaga et al. 1999). The absorbance was read at $570 \mathrm{~nm}$ for MTT assay and at $450 \mathrm{~nm}$ for WST-8 assay by using a microplate reader (Thermo Labsystems Multiscan Spectrum).

\section{Wound healing assay (Scratch assay)}

The wound healing assay was used in this study, because it is a surrogate method for evaluation in vivo tissue healing assays and also allows the researcher to study cell migration and cell interactions (Hoang et al., 2000; Liang et al., 2007). BJ and HaCaT cells were plated in a 24well plate $\left(10 \times 10^{3}\right.$ cells per well $)$ in Eagle's minimal essential medium containing $10 \%$ fetal bovine serum. After $24 \mathrm{~h}$ of cell culture at $37^{\circ} \mathrm{C}$ and $5 \% \mathrm{CO}_{2}$, the $100 \%$ cell confluence was observed before the scratch assay was performed. A sterile yellow $(100 \mu \mathrm{L})$ pipette tip was used to make a straight scratch on the monolayer of cells, stimulating a wound. Wounded monolayers were washed twice with phosphate buffered saline (PBS) to remove cell debris. Then, cells were treated with medium containing FA at different concentrations (1, 5, $10,20 \mu \mathrm{g} \mathrm{mL}^{-1}$ ), which were determined according to proliferation assay results. Negative control cells received only culture medium. Furthermore, wound healing agent Crystalin (10\%) was used as standard wound healing agent for $\mathrm{BJ}$ and $\mathrm{HaCaT}$ cells. $5 \mu \mathrm{g} \mathrm{mL}^{-1}$ citric acid was used also as a solvent control (solvent of FA). Wound healing by migrating cells after FA treatment was observed at 0,12 , and $24^{\text {th }}$ hours by inverted light microscope (Olympus CK40) equipped with a camera. Photographs were analyzed by using Image $J$ software $(\mathrm{NIH}$, USA). The $\%$ relative migration of $\mathrm{BJ}$ and $\mathrm{HaCaT}$ cells treated with FA and controls were calculated according to the following equation:

$\%$ Relative migration $=\frac{\text { Area between cells } 0 \mathrm{~h}-\text { Area between cells } 12 \text { or } 24 \mathrm{~h}}{\text { Area between cells } 0 \mathrm{~h}} \times 100$

\section{Statistical analysis}

All the experiments were carried out triplicate, and obtained data were analyzed by One Way ANOVA (SPSS 20.00 software package program). The statistically significant difference was considered to be $\mathrm{p}<0.05$. The normality of variables was evaluated using the Kolmogorov - Smirnov Z test. The statistical differences between the control and treatment groups were carried out using the non-parametric Mann Whitney Test (for independent samples). The correlations between different variables were determined using the Spearman Rank Correlation Test.

\section{RESULTS AND DISCUSSION}

\section{DPPH radical scavenging activity}

The data on the DPPH radical scavenging activity of the fulvic acid (FA) are given in Table 1. Tested concentrations of FA exhibited very low DPPH radical scavenging activity. The DPPH radical scavenging activity of the $100 \mu \mathrm{g}$ $\mathrm{mL}^{-1} \quad \mathrm{FA}$ (the highest concentration in experiment) was determined as $12.37 \%$. DPPH radical scavenging activity of citric acid, and rutin and ascorbic acid are $24.22 \%, 91.75 \%$ and $90.95 \%$, respectively. 


\section{$\mathrm{H}_{2} \mathrm{O}_{2}$ scavenging activity}

The data concerning the hydrogen peroxide $\left(\mathrm{H}_{2} \mathrm{O}_{2}\right)$ scavenging activity of FA are present in Table 1. According to these data 1, 5 10 and $20 \mu \mathrm{g} \mathrm{mL} \mathrm{m}^{-1}$ concentrations of FA exhibited high $\mathrm{H}_{2} \mathrm{O}_{2}$ scavenging activities ( $\mathrm{p}$
<0.05). With an increase in FA concentration from $30 \mu \mathrm{g} / \mathrm{mL}$, the $\mathrm{H}_{2} \mathrm{O}_{2}$ scavenging activity began to decline, and the $\mathrm{H}_{2} \mathrm{O}_{2}$ scavenging activity at the highest concentration of $100 \mu \mathrm{g}$ $\mathrm{mL}^{-1}$ decreased to $25.78 \%$.

Table1. DPPH radical scavenging and $\mathrm{H}_{2} \mathrm{O}_{2}$ scavenging activities of Fulvic acid

\begin{tabular}{|c|c|c|}
\hline Concentrations & $\begin{array}{c}\text { DPPH scavenging activity } \\
(\% \pm \text { SD })\end{array}$ & $\begin{array}{c}\mathrm{H}_{2} \mathrm{O}_{2} \text { scavenging activity } \\
(\% \pm \mathrm{SD})\end{array}$ \\
\hline $1 \mu \mathrm{g} \mathrm{mL} L^{-1} \mathrm{FA}$ & $9.28 \pm 0.006$ & $86.72 \pm 0.001 *$ \\
\hline $5 \mu \mathrm{g} \mathrm{mL}{ }^{-1} \mathrm{FA}$ & $9.28 \pm 0.005$ & $71.10 \pm 0.041 *$ \\
\hline $10 \mu \mathrm{g} \mathrm{mL}^{-1} \mathrm{FA}$ & $1.55 \pm 0.015$ & $74.61 \pm 0.022 *$ \\
\hline $20 \mu \mathrm{g} \mathrm{mL}^{-1} \mathrm{FA}$ & $1.00 \pm 0.007$ & $75.00 \pm 0.011 *$ \\
\hline $30 \mu \mathrm{g} \mathrm{mL}^{-1} \mathrm{FA}$ & $1.03 \pm 0.008$ & $39.06 \pm 0.045^{*}$ \\
\hline $50 \mu \mathrm{g} \mathrm{mL}^{-1} \mathrm{FA}$ & $5.79 \pm 0.004$ & $35.16 \pm 0.019 *$ \\
\hline $100 \mu \mathrm{g} \mathrm{mL}^{-1} \mathrm{FA}$ & $12.37 \pm 0.011$ & $25.78 \pm 0.070$ \\
\hline Citric acid $\left(50 \mu \mathrm{g} \mathrm{mL}^{-1}\right)$ (solvent control) & $24.22 \pm 0.005$ & $80.86 \pm 0.019 *$ \\
\hline Rutin $\left(10 \mu \mathrm{g} \mathrm{mL}^{-1}\right)^{\mathrm{x}}$ & $91.75 \pm 0.003 *$ & --- \\
\hline Ascorbic acid $\left(10 \mu \mathrm{g} \mathrm{mL}^{-1}\right)^{\mathrm{xx}}$ & $90.95 \pm 0.012 *$ & $41.73 \pm 0.047 *$ \\
\hline
\end{tabular}

FA, a soluble class of humic substances at each $\mathrm{pH}$ value, is a mixture of polyphenolic acid compounds that occur as a result of chemical and biological degradation of organic materials such as dead plants, microbes and animals (Motojima et al., 2011; Guzman-Martinez et al., 2013). There are studies to investigating antioxidant activity of FA obtained from different natural sources e.g. FA isolated from dissolved sludge, FA purified from coal mines in China, and FA isolated from turf (Ueda et al., 2004; Tachibana et al., 2004; Motojima et al., 2011; Gao et al., 2018). In our study, although FA showed high $\mathrm{H}_{2} \mathrm{O}_{2}$ scavenging activity in comparison with control, it exhibited low DPPH radical scavenging activity.

DPPH can only be soluble in organic solvent and interference of absorbance from the sample compounds could be a problem for quantitative analysis (Arnao, 2000). In addition, the spectrophotometric measurements can be affected by compounds, such as carotenoids, that absorb at the wavelength of determination as well as by the turbidity of the sample (Apak et al., 2013). FA solution has a dark yellow to brown color. Although the color is very light at low concentrations, the color is getting darker at higher concentrations. As the color of the FA solution could be interfered, the measured absorbance values in DPPH and $\mathrm{H}_{2} \mathrm{O}_{2}$ assays may be high. Interference of color of FA may have led to a low rate of antioxidant activity.

\section{Effect of fulvic acid on the proliferation and viability of $\mathrm{BJ}$ and $\mathrm{HaCaT}$ cells}

Effect of FA on the proliferation and viability of BJ cells are present in Table 2 . MTT test results showed that $20 \mu \mathrm{g} \mathrm{mL}^{-1}$ FA treatment decreased cell viability and proliferation significantly in comparison with control (p $<0.05)$. However, other FA concentrations have not significantly effect on BJ cell viability and proliferation. Citric acid and Crystalin (10\%) also have not an important effect on cell viability and proliferation.

According to WST-8 test results, it was observed that the 1 and $5 \mu \mathrm{g} \mathrm{mL}^{-1}$ FA increased the proliferation of BJ cells at $24 \mathrm{~h}$, but reduced the proliferation after treatment for $48 \mathrm{~h}$. The decrease in cell proliferation after $48 \mathrm{~h}$ treatment of 5 and $10 \mu \mathrm{g} \mathrm{mL} \mathrm{m}^{-1} \mathrm{FA}$ was statistically 
significant $(\mathrm{p}<0.05)$ in comparison with control. $20 \mu \mathrm{g} \mathrm{mL}{ }^{-1}$ FA treatment for 24 and $48 \mathrm{~h}$ decreased cell viability and proliferation significantly $(\mathrm{p}<0.05)$. Citric acid and Crystalin
(10\%) decreased cell viability and proliferation insignificantly. Results of the MTT and WST-8 assays exhibited that $20 \mu \mathrm{g} \mathrm{mL} \mathrm{m}^{-1}$ FA significantly reduced viability and proliferation of BJ cells.

Table 2. Effect of Fulvic acid on proliferation of BJ human foreskin fibroblast cells

\begin{tabular}{|c|c|c|c|c|c|}
\hline \multirow{3}{*}{ Groups } & \multirow{3}{*}{ Concentrations } & \multicolumn{4}{|c|}{ Proliferation $(\% \pm$ SD) } \\
\hline & & \multicolumn{2}{|c|}{ MTT assay } & \multicolumn{2}{|c|}{ WST-8 assay } \\
\hline & & $24 \mathrm{~h}$ & $48 \mathrm{~h}$ & $24 \mathrm{~h}$ & $48 \mathrm{~h}$ \\
\hline Negative Control & --- & $100.00 \pm 0.00$ & $100.00 \pm 0.00$ & $100.00 \pm 0.00$ & $100.00 \pm 0.00$ \\
\hline $\begin{array}{c}\text { Citric acid } \\
\text { (solvent control) }\end{array}$ & $5 \mu \mathrm{g} \mathrm{mL}^{-1}$ & $101.01 \pm 0.191$ & $96.36 \pm 0.126$ & $90.20 \pm 0.074$ & $87.40 \pm 0.060$ \\
\hline $\begin{array}{c}\text { Crystalin } \\
\text { (standard agent) }\end{array}$ & $\% 10$ & $96.03 \pm 0.162$ & $97.15 \pm 0.177$ & $97.89 \pm 0.050$ & $87.73 \pm 0.109$ \\
\hline $\begin{array}{c}\text { Fulvic } \\
\text { Acid }\end{array}$ & $\begin{array}{l}1 \mu \mathrm{g} \mathrm{mL} \mathrm{mL}^{-1} \\
5 \mu \mathrm{g} \mathrm{mL} \\
10 \mu \mathrm{g} \mathrm{mL}^{-1} \\
20 \mu \mathrm{g} \mathrm{mL}^{-1}\end{array}$ & $\begin{array}{c}102.40 \pm 0.168 \\
102.35 \pm 0.079 \\
92.98 \pm 0.271 \\
83.34 \pm 0.102 *\end{array}$ & $\begin{array}{c}102.64 \pm 0.119 \\
97.98 \pm 0.037 \\
87.87 \pm 0.118 \\
84.84 \pm 0.038^{*}\end{array}$ & $\begin{array}{c}114.15 \pm 0.290 \\
106.60 \pm 0.061 \\
87.89 \pm 0.060 \\
81.02 \pm 0.057 *\end{array}$ & $\begin{array}{c}98.85 \pm 0.049 \\
84.60 \pm 0.103^{*} \\
85.44 \pm 0.010^{*} \\
82.93 \pm 0.009^{*}\end{array}$ \\
\hline
\end{tabular}

$* \mathrm{p}<0.05$

Results about effect of FA on proliferation and viability of $\mathrm{HaCaT}$ cells are presented in Table 3. MTT test results showed that FA treatment decreased cell viability and proliferation concentration dependently. After $24 \mathrm{~h}$ treatment, decrease of cell viability and proliferation was found statistically significant at all FA concentrations. $20 \mu \mathrm{g} \mathrm{mL}^{-1}$ FA decreased cell viability and proliferation statistically significant after 24 and $48 \mathrm{~h}$ treatment ( $\mathrm{p}<0.05$ ).
According to WST-8 test results, it was observed that none of the FA concentrations affected HaCaT cell viability and proliferation significantly, in comparison with control groups. Citric acid and Crystalin decreased cell viability and proliferation after $24 \mathrm{~h}$, but they increased cell viability and proliferation after $48 \mathrm{~h}$ treatment.

Table 3. Effect of Fulvic acid on proliferation of HaCaT human immortalized keratinocyte cells

\begin{tabular}{|c|c|c|c|c|c|}
\hline \multirow{3}{*}{ Groups } & \multirow{3}{*}{ Concentrations } & \multicolumn{4}{|c|}{ Proliferation $(\% \pm$ SD) } \\
\hline & & \multicolumn{2}{|c|}{ MTT assay } & \multicolumn{2}{|c|}{ WST-8 assay } \\
\hline & & $24 \mathrm{~h}$ & $48 \mathrm{~h}$ & $24 \mathrm{~h}$ & $48 \mathrm{~h}$ \\
\hline Negative Control & --- & $100.00 \pm 0.00$ & $100.00 \pm 0.00$ & $100.00 \pm 0.00$ & $100.00 \pm 0.00$ \\
\hline Citric acid (solvent control) & $5 \mu \mathrm{g} \mathrm{mL}^{-1}$ & $96.10 \pm 0.159$ & $102.66 \pm 0.104$ & $84.38 \pm 0.182 *$ & $101.50 \pm 0.135$ \\
\hline \multirow[t]{2}{*}{ Crystalin (standard agent) } & $\% 10$ & $88.17 \pm 0.076$ & $101.75 \pm 0.259$ & $85.00 \pm 0.604$ & $101.28 \pm 0.935$ \\
\hline & $1 \mu \mathrm{g} \mathrm{mL}^{-1}$ & $83.80 \pm 0.185^{*}$ & $94.81 \pm 0.195$ & $102.01 \pm 0.518$ & $110.70 \pm 0.733$ \\
\hline Fulvic & $5 \mu \mathrm{g} \mathrm{mL}^{-1}$ & $75.19 \pm 0.296^{*}$ & $92.99 \pm 0.137$ & $101.61 \pm 0.539$ & $109.80 \pm 0.434$ \\
\hline \multirow[t]{2}{*}{ Acid } & $10 \mu \mathrm{g} \mathrm{mL}^{-1}$ & $67.40 \pm 0.061^{*}$ & $86.90 \pm 0.104$ & $96.63 \pm 0.325$ & $104.95 \pm 0.268$ \\
\hline & $20 \mu \mathrm{g} \mathrm{mL}^{-1}$ & $58.15 \pm 0.181^{*}$ & $84.18 \pm 0.172 *$ & $92.02 \pm 0.564$ & $100.52 \pm 0.324$ \\
\hline
\end{tabular}

$* p<0.05$

\section{Wound healing effect of fulvic acid in BJ and HaCaT cells}

Data for wound healing efficacy of FA on BJ cells are presented in Table 4 and Figure 3. When obtained data is compared with the control group, it is observed that crystalin has a considerably high wound healing effect at $24^{\text {th }} \mathrm{h}$ and this effect is considerably higher than that the negative control group. However, when the effect of crystalin is compared to the citric acid, it appears that the wound healing effect of citric acid is higher than that of crystalin. $1 \mu \mathrm{g} \mathrm{mL}^{-1} \mathrm{FA}$ has significantly higher wound healing effect than the negative control at $12^{\text {th }}$ and $24^{\text {th }} \mathrm{h}$ but, this effect is lower than that of crystalin and citric acid. 
Investigation of antioxidant and in vitro wound healing activity of Fulvic acid

Table 4. Wound healing effect of Fulvic acid on BJ human foreskin fibroblast cell

\begin{tabular}{|c|c|c|c|}
\hline \multirow[b]{2}{*}{ Groups } & \multicolumn{3}{|c|}{ Wound healing $(\% \pm$ SD $)$} \\
\hline & $\begin{array}{ll}\mathbf{0} & \mathbf{h}\end{array}$ & $12 \mathrm{~h}$ & $24 \mathrm{~h}$ \\
\hline Negative Control & $0.00 \pm 0.00$ & $28.42 \pm 0.220$ & $45.63 \pm 0.630$ \\
\hline Citric acid (Solvent control) & $0.00 \pm 0.00$ & $35.74 \pm 0.200 *$ & $62.55 \pm 0.200^{*}$ \\
\hline Crystalin (Standard agent) & $0.00 \pm 0.00$ & $34.14 \pm 0.140 *$ & $55.29 \pm 0.090^{*}$ \\
\hline $1 \mu \mathrm{g} \mathrm{mL}^{-1} \mathrm{FA}$ & $0.00 \pm 0.00$ & $36.69 \pm 0.190 *$ & $53.25 \pm 0.250 *$ \\
\hline $5 \mu \mathrm{g} \mathrm{mL}^{-1} \mathrm{FA}$ & $0.00 \pm 0.00$ & $30.77 \pm 0.100$ & $47.53 \pm 0.200$ \\
\hline $10 \mu \mathrm{g} \mathrm{mL}^{-1} \mathrm{FA}$ & $0.00 \pm 0.00$ & $17.58 \pm 0.200 *$ & $53.30 \pm 0.361^{*}$ \\
\hline $20 \mu \mathrm{g} \mathrm{mL}^{-1} \mathrm{FA}$ & $0.00 \pm 0.00$ & $28.48 \pm 0.300$ & $45.45 \pm 0.250$ \\
\hline
\end{tabular}
${ }^{*} \mathrm{p}<0.05$

5 and $10 \mu \mathrm{g} \mathrm{mL}^{-1} \mathrm{FA}$ remained far behind the control for the first $12 \mathrm{~h}$ and did not show any significant wound healing effect. However, at $24 \mathrm{~h}$, it surprisingly showed a significant wound-healing effect compared to the negative control. $20 \mu \mathrm{g} \mathrm{mL} \mathrm{m}^{-1} \mathrm{FA}$ did not show any significant wound healing effect on BJ cells. The citric acid showed considerable wound healing effect from the $12^{\text {th }} \mathrm{h}$ and reached a high value $(62.55 \%)$ at $24^{\text {th }}$ hour compared with negative control group, and FA and crystalin ( $\mathrm{p}<0.05)$.
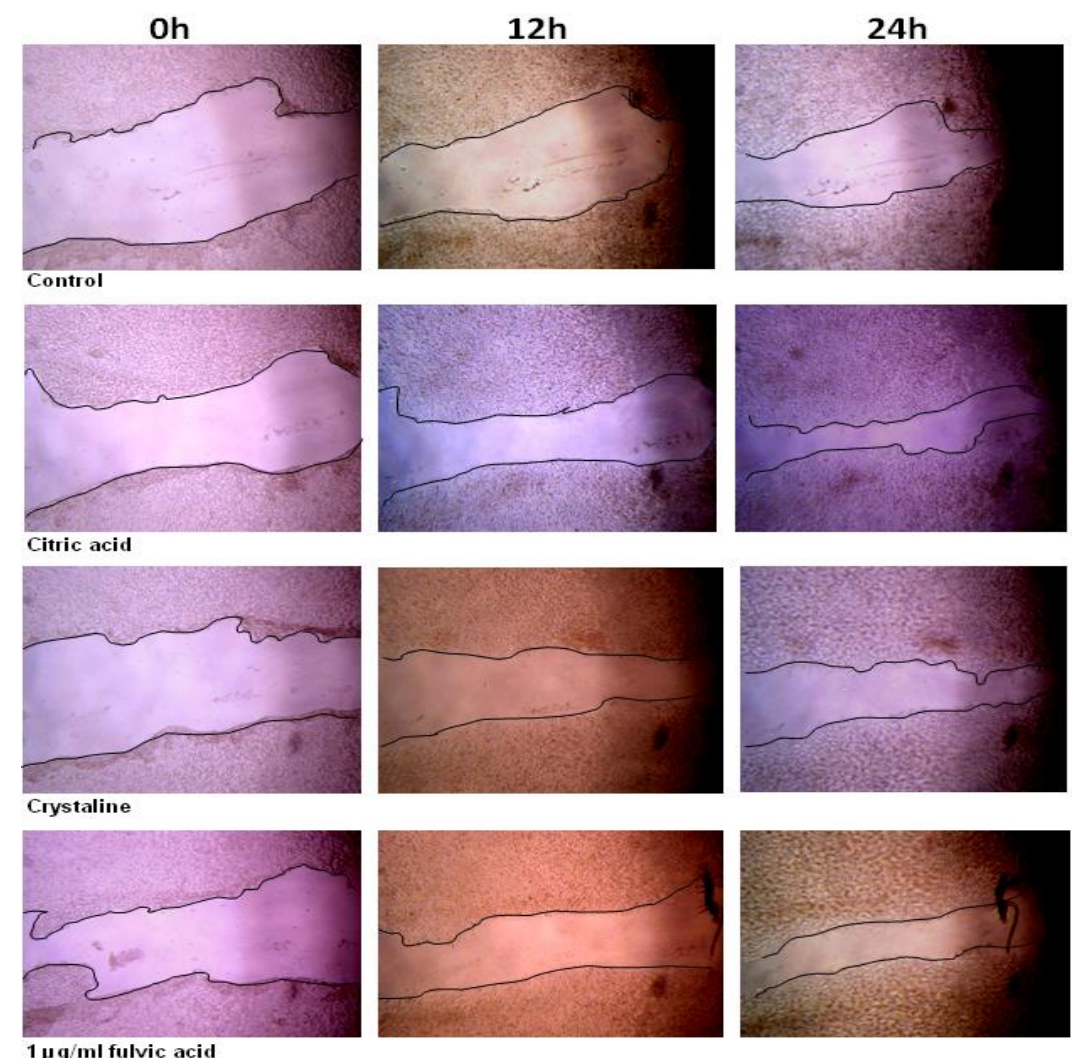

Fig.3. Micrographs showing the coverage of scratched wounds by BJ cells in the absence or presence of fulvic acid

Data for wound healing efficacy of FA on HaCaT cells are presented in Table 5 and Figure 4. According to the findings, all concentrations of FA exhibited wound healing effects at a significant level on $\mathrm{HaCaT}$ cells relative to the negative control group at the $12^{\text {th }} \mathrm{h}$. The wound healing effects of the other FA concentrations except $10 \mu \mathrm{g} \mathrm{mL}^{-1}$ were found to be higher than that of citric acid and crystalin. 
At $24^{\text {th }} \mathrm{h}$, all concentrations of FA showed significant wound healing effects in $\mathrm{HaCaT}$ cells in comparison with the negative control group, citric acid and crystalin $(p<0.05)$. The most effective concentration of FA was $1 \mu \mathrm{g} \mathrm{mL} \mathrm{m}^{-1} \mathrm{FA}$ on $\mathrm{HaCaT}$ cells at the end of the 24-hour treatment period.

Table 5. Wound healing effect of Fulvic acid on HaCaT human immortalized keratinocyte cells

\begin{tabular}{lccc}
\hline & \multicolumn{3}{c}{ Wound healing (\%) } \\
\cline { 2 - 4 } Groups & $\mathbf{0 ~ h}$ & $\mathbf{1 2 ~ h}$ & $\mathbf{2 4}$ h \\
\hline Negative Control & $0.00 \pm 0.00$ & $9.24 \pm 1.61$ & $31.91 \pm 2.23$ \\
Citric acid (Solvent control) & $0.00 \pm 0.00$ & $18.12 \pm 0.20^{*}$ & $37.02 \pm 5.87$ \\
Crystalin (Standard agent) & $0.00 \pm 0.00$ & $18.82 \pm 2.44^{*}$ & $37.52 \pm 1.76$ \\
$1 \mu \mathrm{g} \mathrm{mL}^{-1} \mathrm{FA}$ & $0.00 \pm 0.00$ & $30.08 \pm 2.29^{*}$ & $63.82 \pm 6.35^{*}$ \\
$5 \mu \mathrm{g} \mathrm{mL}$ & $\mathrm{FA}$ & $23.81 \pm 4.81^{*}$ & $49.82 \pm 4.98^{*}$ \\
$10 \mu \mathrm{g} \mathrm{mL}^{-1} \mathrm{FA}$ & $0.00 \pm 0.00$ & $18.35 \pm 4.93^{*}$ & $59.40 \pm 4.90^{*}$ \\
$20 \mu \mathrm{g} \mathrm{mL}^{-1} \mathrm{FA}$ & $0.00 \pm 0.00$ & $21.03 \pm 6.53^{*}$ & $53.20 \pm 3.52^{*}$ \\
\hline
\end{tabular}

*p $<0.05$
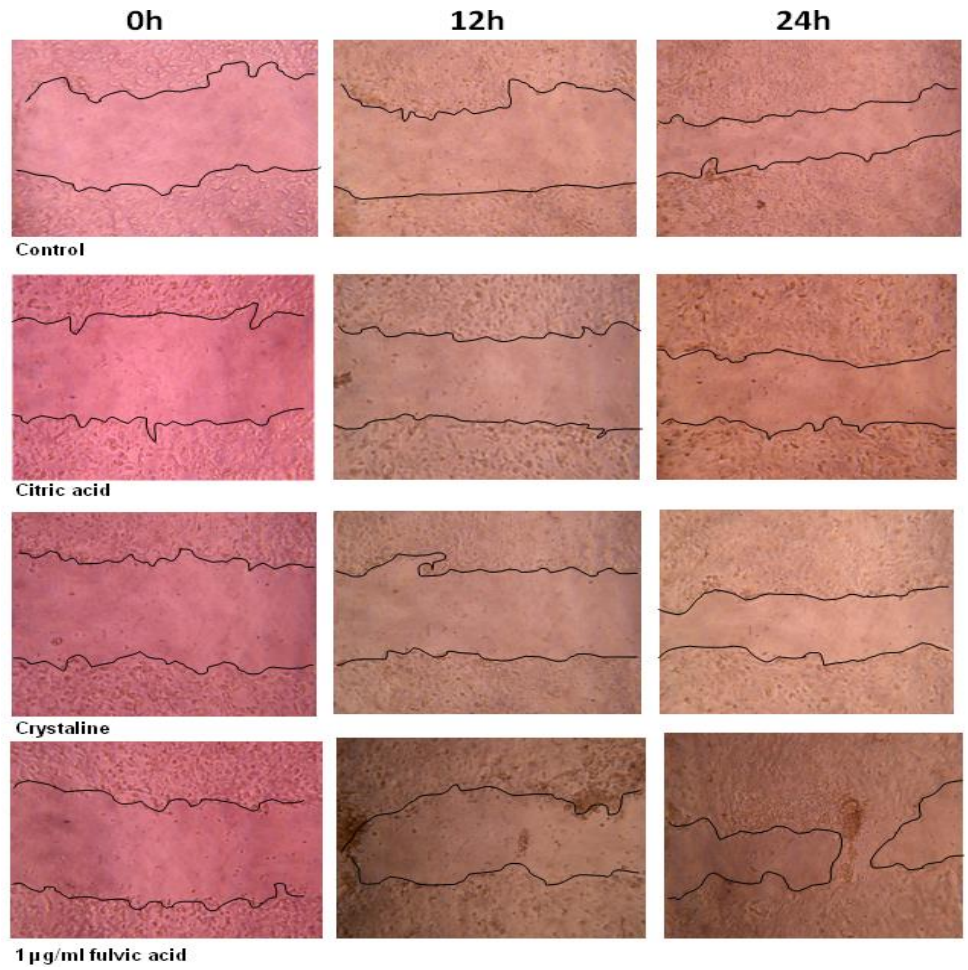

Fig.4. Micrographs showing the coverage of scratched wounds by HaCaT cells in the absence or presence of fulvic acid

Wound healing is a highly complex biochemical event that develops in the injured organism. Disruption or prolongation of any stage of wound healing causes the wound to become chronic, which may not be delayed or improved in wound healing (Guo and Di Pietro, 2006). In our study, FA increased wound healing in both $\mathrm{BJ}$ and $\mathrm{HaCaT}$ cells related to the duration of administration. The healing process requires extra oxygen, and this demand appears in the first minute after wounding due to phagocytosis, the main event in wound healing process, which is very oxygen-consumptive (Jurcsik, 1994). Humic acid (HA) can increase the production of active oxygen during the wound healing process and in anti-tumor process. Reports by Jurcsik have shown that when HA was incubated with Hep-2 cancer cell line for 24 hours, the proliferation of the HEp-2 cancer cell line was found to be decreased by $65 \%$ as compared to the control cell line (68). HA can inhibit the tumor cell multiplication by 
intercalating with DNA, blocks the DNA opening and destroys the DNA by producing the reactive oxygen derivatives (Jurcsik, 1994). Fulvic acid may also increase wound healing with a mechanism similar to humic acid.

In the elderly people and diabetic patients, it is often the case that the above-mentioned stages of healing of wounds become late. Oxidative stress is also one of the factors that contribute to impaired wound healing in nonhealing wounds (Schafer and Warner, 2008). Endogenous antioxidant's levels such as glutathione and vitamin $\mathrm{E}$ are diminished under conditions that impair wound healing including aging and diabetes (Rasik and Shukla, 2000; Ullah et al., 2016). Therefore, the wound healing potential of exogenous antioxidants has received an increasing interest.

Fibroblast proliferation and migration are important factor in wound healing. This event plays an important role in the healing process by initiating the proliferative phase of repair (Fronza et al., 2009; Ebeling et al., 2014; Ascione et al., 2016). The results of proliferation tests (MTT and WST-8) of BJ and HaCaT cells were found different from the wound healing assay results. Cell division (proliferation) is an irreversible process, and it is started by a single and rapid event, while migration is a reversible process (De Donatis and Cirri, 2009). This may be the reason for the difference between the results of cell proliferation and wound healing.

\section{CONCLUSION}

The results from our study show that fulvic acid purified from Hüsamlar Leonarditis exhibit a low DPPH radical scavenging activity, but exhibited high $\mathrm{H}_{2} \mathrm{O}_{2}$ scavenging activity at low concentrations. Fulvic acid accelerated wound healing especially in $\mathrm{HaCaT}$ cells by increasing cell migration, in comparison with negative control, citric acid, and wound healing agent crystalin. Therefore, fulvic acid may be a promising agent for wound healing efficacy, especially at low concentrations. However, in order to reach a more accurate judgment in this regard, more detailed studies should be carried out using different test systems, including in vivo tests.

\section{ACKNOWLEDGEMENT}

We acknowledge Adnan Menderes University Scientific Research Foundation for financial support (Project No: FEF-15035).

\section{REFERENCES}

Apak R, Gorinstein S, Bohm V, Schaich KM, Özyürek M, et al. 2013. Methods of measurement and evaluation of natural antioxidant capacity/activity (IUPAC Technical Report). Pure and Applied Chemistry, 85: 957-998.

Arnao MB, 2000. Some methodological problems in the determination of antioxidant activity using chromogen radicals: a practice case. $\mathrm{Tr}$ Food Sc Technol, 11(11): 419-421.

Ascione F, Vasaturo A, Caserta S, D'Esposito V, Formisano P, Guido S, 2016. Comparison between fibroblast wound healing and cell random migration assays in vitro. Experimental Cell Research, 347: 123-132. Barrientos S, Stojadinovic O, Golinko MS, Brem H, Tomic-Canic M, 2008. Growth factors and cytokines in wound healing. Wound Repair Regen., 16: 585-601.

Brand-Williams W, Cuvelier ME, Berset C, 1995. Use of free radical method to evaluate antioxidant activity. Food Science and Technology, 28: 25-30.

Braun-falco O, Plewig G, Wolff HH, Burgdorf WHC (Eds.). 2000. Dermatology. Second ed. Springer, Berlin/Heidelberg/Newyork.

Cornejo A, Jiménez JM, Caballero L, Melo F, Maccioni RB, 2011. Fulvic acid inhibits aggregation and promotes disassembly of tau fibrils associated with Alzheimer's disease. J Alzheimers Dis., 27: 143-153. 
De Donatis A, Cirri P, 2009. Understanding the specificity of receptor tyrosine kinases signaling. Commun Integr Biol., 1: 156157.

Ebeling S, Naumann K, Pollok S et al. 2014. From a traditional medicinal plant to rational drug: Understanding the clinically proven wound healing efficacy of birch bark extract. PLoS One, 9: e86147.

Fronza M, Heinzmann B, Hamburger M et al., 2009. Determination of the wound healing effect of Calendula extracts using the scratch assay with 3T3 fibroblasts. J Ethnopharmacol., 126: 463-467.

Gao Y, Zhu J, Bao H, Hector V, Zhao B, Chu Z, 2018. Effect of lignite fulvic acid on growth, antioxidant ability, and HSP70 of Pacific white shrimp, Litopenaeus vannamei. Aquaculture Iternational, 26(6): 1519-1530.

Guo S, Di Pietro LA, 2006. Factors affecting wound healing. J Dent Res., 89: 219-29.

Guzmán-Martinez L, Farías GA, Maccioni RB, 2013. Tau oligomers as potential targets for Alzheimer's diagnosis and novel drugs. Frony Neurol., 4: 167.

Hoang AM, Oates TW, Cochran DL, 2000. In vitro wound healing responses to enamel matrix derivative. Journal of Periodontology, 71(8): 1270-1277.

Jurcsik I, 1994. Possibilities of applying humic acids in medicine, wound healing and cancer therapy. In: Senesi N, Milano TM., editors. Humic Substances in the Global Environment. Newyork: Elsevier; 1994. pp. 1331-1336.

Liang CC, Park AY, Guan JL, 2007. In vitro scratch assay: a convenient and inexpensive method for analysis of cell migration in vitro. Nature Protocols, 2(2): 329-333.

MacCarthy P, 2001. The principles of humic substances. Soil Sci., 166: 738-751.
Martin P, 1997. Wound healing-aiming for perfect skin regeneration. Science, 276: $75-81$.

Mossman T, 1983. Rapid colorimetric assay for cellular growth and survival: application to proliferation and cytotoxicity assays. J. Immunol. Methods, 65: 55-63.

Motojima HO, Villareal M, Han J, Isoda H, 2011. Microarray analysis of immediatetype allergy in KU812 cells in response to fulvic acid. Cytotechnology, 63: 181-190.

Rasik AM, Shukla A, 2000. Antioxidant status in delayed healing type of wounds. Int. J Exp Pathol., 81: 257-263.

Ruch RJ, Cheng SJ, Klaunig JE, 1989. Prevention of cyto-toxicity and inhibition of intercellular communication by antioxidant catechins isolated from Chinese green tea. Carcinogenesis, 10(6): 1003-1008.

Schafer M, Werner S, 2008. Oxidative stres in normal and impaired wound repair. Pharmacol Res., 58: 165-171.

Sherry L, Millhouse E, Lappin DF, Murray C, Culshaw S, Nile CJ,Ramage G, 2013. Investigating the biological properties of carbohydrate derived fulvic acid (CHDFA) as a potential nove therapy fort he management of oral biofilm infections. BMC Oral Health, 13: 47.

Smith MB, March J, 2001. March's Advanced Organic Chemistry, Reactions, Mechanisms, and Structure, Wiley, 484.

Sönmez YM, 2011 Fulvik Asit Prosesinin Geliştirilmesi ve Tasarımı (Development and Design of Fulvic Acid Process). M.Sc. Thesis, Gazi University, Institute of Science and Technology, Ankara, Turkey.

Tachibana Y, Hiribe S, Tawa R, 2004. Studies of antioxidative activity of humic substances in peat (1). Trace Nutrients Res., 23: 104108. 
Tominaga H, Ishiyama M, Ohseto F, Sasamoto K, Hamamoto T, Suzuki K, Watanabe M, 1999. A water-soluble tetrazolium salt useful for colorimetric cell viability assay. Analytical Communications, 36: 47-50.

Ueda J, Ikota N, Shinozuka T, Yamaguchi T, 2004. Reactive oxygen species scavenging ability of a new compound derived from weathered coal. Specrochimica Acta Part A, 60: 2487-2492.

Ullah A, Khan A, Khan I, 2016. Diabetes mellitus and oxidative stres-A concise review. Saudi Pharmaceutical Journal, 24: 547-553.
Van Rensburg CEJ, Malfeld SCK, Dekker J, 2001. Topical application of oxifulvic acid suppressess the cutaneous immune response in mice. Drug Dev Res., 53: 2932.

Winkler J, Ghosh S, 2018. Therapeutic potential of fulvic acid in chronic inflammatory diseases and diabetes. Journal of Diabetes Research, https://doi.org/10.1155/2018/5391014

Zouboulis CC, 2000. Human skin: an independent peripheral endocrine organ. Hormone Research in Paediatrics, 54: 230242. 